\title{
The Value of Corporate Social Performance: The Case of a Local Public Transport Company
}

\author{
Agliata Francesco $^{1}$, Caterina Ferrone ${ }^{2} \&$ Danilo Tuccillo $^{1}$ \\ ${ }^{1}$ Assistant Professor in Accounting - University of Campania "Luigi Vanvitelli”, Italy \\ ${ }^{2}$ Research Fellowship in Accounting - University of Naples "Federico II", Italy \\ Correspondence: Agliata Francesco, Assistant Professor in Accounting - University of Campania "Luigi \\ Vanvitelli”, Italy. E-mail: f.agliata@unina.it
}

Received: July 26, 2017

doi:10.5539/ijbm.v12n10p58
Accepted: September 5, $2017 \quad$ Online Published: September 17, 2017
URL: https://doi.org/10.5539/ijbm.v12n10p58

\begin{abstract}
The Corporate Social Responsibility is traditionally viewed not as a productive investment, but like an expense of defensive character, destined to consume resources without producing new value. However, in the actual context, the public interest cannot be an objective only for the Public Administration; each enterprise should integrate in the management choices a CSR strategy (Borgonovi \& Rusconi, 2008).

The CSR is, primarily, intended as the ability to follow those lines of action which are desirable in relation to the aims and values of our society (Bowen, 1953). The development of studies on CSR has produced subsequently further definition, which tend to emphasize the importance of expectations of the community and the resulting social role played by itself in increasing weal (Frederick, 1960); to the definition of corporate social responsibility contained in the EU Green Paper, which identifies CSR as those behaviours oriented to the integration between economic, social and environmental variables in the management company (EU, 2001).

This work aims to investigate the potential of investment in CSR in terms of creating new value as part of a new definition of sustainable business performance based on the joint and balanced maximization of economic, social and environmental objectives (Elkington, 1997). The objective of this research is to verify the impact on business performance due to the implementation of a specific design of CSR, named Contact, in a local public transport company of medium/big size (Turnover $€$ 56.613.130, Employees 1.341).
\end{abstract}

Keywords: corporate social responsibility, corporate social performance, local public transport, social and business performance

\section{Introduction}

The term "Corporate Social Responsibility" urges to focus on the conditions and modalities of the processes of the economic production, intended as determiners attributing to responsibility, certainly not or not only, the compliance with law, but rather the social-ethical impact which the development of the economic activities may have on the reference field.

Corporate social responsibility was traditionally considered as a non-productive investment, as an expenditure of defensive nature, planned to waste resources without producing new wealth, to protect on the one hand, the corporate image and on the other, the public interest. However, nowadays, public interest cannot be a goal just for Public Administration; each company should integrate a strategy of social responsibility in management decisions (Borgonovi \& Rusconi, 2008).

Currently, there is a widespread belief that companies have obligations that go beyond the responsible use of scarce resources. The creation of economic value, meant as output production of higher value compared to the resources wasted in the production process, is a necessary but not sufficient condition to ensure an entrepreneurial action characterized by effectiveness and efficiency as required by corporate entities (Giannessi, 1960, p. 74).

If, therefore, the creation of economic value through the productive combination justifies the seizure of certain assets from the community, the only economic value created do not ensure that management has been carried out in harmony with the reference field. In other words, the economic balance does not necessarily guarantee an 
adequate satisfaction of all the stakeholders. The creation of value, which the company must constantly pursue, cannot, or it can no longer be conceived just as creation of economic value.

Hence, the value created extends its meaning beyond the economic and financial value to incorporate also the social and environmental dimensions. The company consequently, undertakes a series of actions as a result of management decisions aimed at creating value, taking into account all the interests involved in business life. Considering that not all of these interests are economic, or exclusively economic, the value created by the company must go beyond this dimension (Onida, 1954).

Through the satisfaction of stakeholders' expectations, the implementation of social responsibility actions encourages the development of strategies aimed to create value in the long term, allowing the acquisition of a sustainable competitive advantage (Elkington, 1977 \& Willard, 2002). The economic, social and environmental dimensions, mutually interconnected, therefore, should guide management decisions towards the achievement of the objectives through the expansion and the consolidation of competitive advantage, favouring the long-term perspective (Molteni, 2004, p. 15).

Social responsibility should be considered as deeply linked to the development of company. A socially responsible company has the task of identifying the legitimate expectations of all the stakeholders and make them a substantial part of their own strategies. In the long term, the economic social and environmental outlooks, must be considered mutually entwined; one can not be separated from the other without risking to compromise the sustainable development of the corporate organization.

For the company, being able to understand and consider the link between Corporate Social Responsibility and creation of value, produces some problems concerning, not only strategic orientation and formulation of management decisions, but also analysis and evaluation of expenditures which are not considered investments so far. For it, to summarize, investing in the creation of stable and profitable relationships with internal and external parties interested in its activities, is a strategic choice enabling the achievement of lasting stability. Within such a stability the ability to create value should be analysed and evaluated.

\section{Theoretical Background}

A first theoretical systematization of the studies on Corporate Social Responsibility can be found in the thought of Bowen, unanimously recognized as the "father" of Corporate Social Responsibility.

Bowen, on the basis that the larger businesses are vital centers of power whose decisions and actions affect the life of society from different points of view, gave a first definition of corporate social responsibility, intended as "obligations of businessmen to pursue those policies, to make those decisions, or to follow those lines of action which are desirable in terms of the objectives and values of our society." (Bowen, 1953, p. 6).

Such a vision would lead company towards additional objectives as regards to the financial-economic ones, directing its attention to the fulfilment of voluntary actions contributing to the resolution or prevention of social iniquities.

Most of the studies of that period were aimed at analyzing the positive and negative externalities of business management from pollution to employment. The focus of the investigations was mainly on out-put, on 'product' in a broad sense, or rather, on external effects derivable from the productive economic activity (Epstein, 1978).

In the Sixties Corporate Social Responsibility (CSR) emerged definitely becoming subject of remarkable contributions, with the first attempts to formalize more accurately its basic concepts, among which stood out those of Davis and Frederick.

Davis was mainly known for his famous Iron Law of Responsibility, which established a strong link between power and corporate social responsibility: social responsibility of businessmen need to be commensurate with their social power (Davis, 1960).

According to Davis, in fact, avoiding such a responsibility would lead to a gradual corrosion of power. In that sense, he can be considered a forerunner because he guessed how socially responsible decisions can be justified by the fact that an extensive and complex process of social acceptance, in a long period, may generate benefits for the company.

Frederick, on the contrary, sought a more detailed definition of social responsibility, emphasizing the importance of the expectations of the community where the company is located and the resulting social role assigned to it in increasing its wealth (Frederick, 1986).

Subsequently, it gradually emerged a corporate social responsibility going beyond economic and legal obligations, even if concrete contents were not yet clearly identified and defined. 
In the same period, McGuire argued that company should act as any good citizen, directing his behaviour to the general interests of policy, community welfare, education, worrying about the "happiness" of its employees and of "social world "in general (McGuire, 1963).

Hence, the idea of "corporate citizenship", originating from McGuire's thought, considering company as any individual of a socio-political community and, as such, bearer of a set of rights and responsibilities that make it interdependent with the others parties of the reference community.

According to the right of citizenship, the social role of a company was mainly founded on two fundamental concepts:

- A company does not belong the single legal owner of assets, but to all the parties involved in their use;

- A company, led to incur costs and assume obligations, has a responsibility towards society.

Only towards the end of the decade, Walton came to point out that corporate social responsibility implies a certain degree of voluntary action, as opposed to coercion, as well as the acceptance of the costs for which it might not be possible to define and measure any immediate or direct return (Walton, 1967).

It emerged thus a first group of theoretical contributions in which social responsibility was conceived as a set of behaviours intended to have a positive impact on the reference community, but not on the economicity/performance. Therefore, it was a matter of defining a minimum set of choices and behaviours able to demonstrate the adherence of company to laws and common moral. More than socially responsible, a company with such an approach could be defined socially acceptable.

During the second phase, in the Seventies, on the one hand there were more attempts to find a shared definition of CSR and on the other, a series of doctrinal contributions aimed at enriching mainly four groups of studies aroused.

The first one sought to identify which features corporate behaviours should have in order to be classified as socially responsible.

In this line of thought Davis brought back to the fore the proposition of the element of voluntarism, pointing out that CSR begins where the law stops: a company can not be considered socially responsible if it only complies with the minimum obligations in accordance with the law (Dawis, 1973).

In such a general thought process, Carroll elaborated the most well-known model during this phase of studies. The approach of this author proposed an idea of social responsibility in which company was seen as "passive agent" of a set of external expectations developing essentially through four dimensions and, on which basis, social responsibility "includes economic, legal, ethical and discretionary expectations that society has of organizations at a given point in time" (Carroll, 1991).

The second group explored the weight of socio-cultural context, also clearly in response to the movements which, between the late Sixties and the early Seventies, fought for the respect of environment, workplace safety, the protection of consumers and workers.

Johnson, for example, by giving a multiform definition of social responsibility, identified four possible points of view, whose main one saw CSR as response to the social norms defining the role of company (Johnson, 1971).

Crucial to this line of thought was the contribution of the Committee for Economic Development (CED), which, in 1971, prepared a report entitled Social Responsibilities of Business Corporation, in which the potential spheres of intervention, subject of social responsibility, were schematized as three concentric circles (Committee for Economic Development, 1971):

- The first circle (the inner) included the responsibilities which the company assumes for the simple performance of its traditional economic functions (e.g. production of goods, creation of new jobs and contribution to the economic growth);

- The middle circle concerned the responsibility to develop the economic function showing particular attention to the values and priorities of society;

- The outer circle, finally, highlighted the availability of the company to consider an active and voluntary involvement in initiatives for social development (e.g. the improvement of the different aspects of a specific social background, such as the economic and cultural conditions of underdevelopment, urban liveability and so on).

The third group of studies evaluated the motivations leading company to act in a socially responsible manner. 
According to Wood, in contemporary literature three possible approaches can be identified according to the type of expectations involved (Wood, 1993):

- An institutional principle, based on the expectations placed on all the companies for their role of economic institutions, whose legitimacy is the key concept. Namely, it was recognized that, in addition to the traditional economic role, companies were also required to play a social role, impossible to avoid without losing their legitimacy, with serious consequences on the economicity;

- An organizational principle, based on the expectations placed in a specific company for what it is and what it does. The organizing principles were inspired by Preston and Post, which, starting from the concept of externalities, argued that a company is not responsible for all the social problems, but only for those that have directly created and for those indirectly interrelated to their actions and their interests (Preston \& Post, 1975);

- An individual principle, recognizing that managers exercise discretion in the process of decision making by defining whether and to what extent to satisfy the expectations of the various parties. By practicing that discretion, individual ethical principles would play a prominent role.

The fourth group of studies turned the attention for social dimension toward the inside of the company and, consequently, it shifted the focus on the development of inner actions able to respond to social needs in order to incorporate them in government (Ackerman \& Bauer, 1976) and, therefore, in the company policies.

This approach put emphasis on the competence of the company management group and its organizational structure.

Many authors started talking about corporate social responsiveness, known as responsiveness, sensitivity, attention to social enterprise, in the sense of ability to act as hoped by society (Frederick, 1994).

Frederick, known as the major theorist of this studies, postulated the overcoming of the concept of corporate social responsibility which had been predominant until the Sixties (to which he briefly referred to as CSR1) and identified the coming out of a new movement of thought, linked to it but distinct: that of corporate social responsiveness, which he called CSR2 and that required, on behalf of company, the acceptance of social obligations resulting from its actions.

More precisely, it was believed that the company was obliged to develop from within the ability to perceive social tensions, to recognize them and respond through management processes and organizational changes aimed at improving the degree of "sensitivity".

This setting was then confirmed by other authors such as Carroll, who argued: "CSR1 (...) has ethical or moral threads running through it and, hence, it is problematic. By contrast CSR2 (...)does not have moral or ethical connotations, but it focus only on the management response processes; these processes should include planning and expectations of the company, organizational activity for the control of social responses to social activities, making social decisions and company policies in social life." (Carroll, 1979).

Even Italian scholars, such as Di Toro, followed this approach, arguing that: "This is a structure (yet, 'mechanical', without moral judgments) consisting of tools aimed at collecting and 'treating' social tensions, in order to direct them to predetermined and formalized business processes." (Di Toro, 1993).

CSR2 was based, therefore, on pragmatic and managerial assumptions, rather than a theoretical discussion of abstract concepts; mechanisms and processes, needed to make Corporate Social Responsibility concrete reality, became the centre of the debate.

The Eighties, the third decade analyzed, were characterized by three mainstreams: the rise of stakeholder theory, the coming out of business ethics studies and the concept of corporate social performance.

The stakeholder theory, in particular, by identifying towards whom, in concrete terms, companies should be responsible, have decisively contributed to reduce the vagueness of the concept of social responsibility.

The stakeholder theory postulated that each group of stakeholders should not be used as means aimed at a goal, but it should participate in defining the general direction of the company. The purpose of the company, therefore, was to coordinate the interests of stakeholders, and in a sense, it was characterized by a set of relationships among groups showing interest in its activities (Freeman, 1984).

The mainstream studies on business ethics, on the contrary, were based on two assumptions: on the one hand, an analysis of the values that should highlight the choices of the company, and on the other, the definition of the rules of conduct informing the different levels of management policies and their system of controls.

Frederick stated about it the emergence of CSR3, that is corporate social rectitude (Frederick, 1986), 
recognizing the need to fill in the legal gap of the two previous approaches with an analysis of ethical values at the basis of all the social behaviours of the companies.

Both with regards to CSR1 and CSR2, indeed, companies act more for the fear of social control, rather than for a real interest in social welfare. CSR3 renders the ethical value to CSR2, in which it was not present, defining, eventually, the path that leads to the elaboration of a social strategy by the company. Ethical values serve as basic element for the creation of company's strategic approach which would enable it to achieve, systematically, social objectives, not just as simple and occasional response to external stimulus.

The author found, therefore, a path consisting of several essential steps that companies should cover to be able to focus effectively on CSR3:

1. The recognition of the centrality of ethics;

2. The training of managers on the subject to make them aware of the importance of ethics;

3. The development of analytical skills in dealing with ethical issues;

4. The alignment of company policies to key values and to ethical culture.

At the same time, the concept of corporate social performance (CSP) became known mainly thanks to the contributions of Carroll.

A first approach to CSP did not focus on behaviour-outcome, rather, it gave attention to the implementation of what Jones called a fair process, through which the interests and the needs of the various stakeholders tried to meet the needs of the company, just through the analysis of the process and methods by which the objectives were identified and the ethical dilemmas were resolved in concrete situations (Jones, 1980).

A second approach, acknowledged by most authors who carried out empirical research, considered CSP specifically in terms of results and tried to analyze them precisely.

This approach was indeed preferable to conduct analysis in this field, since it did not mix input and output as the first did, but it split CSP results from the process that had generated them, setting the standards for the analysis and comparison of the results.

During the Nineties, there was a proliferation of further theoretical contributions that helped to identify four mainstreams.

The first one derived from the assumption that socially responsible behaviours assumed a strategic importance, since they could significantly contribute to strengthen the legitimacy of the company and, therefore, both the sense of involvement in the organization and the long-term relationships with stakeholders.

The second one led strategic management scholars and policy practitioners to the elaboration of the concept of sustainability of entrepreneurship.

Sustainability was meant as approach aimed at creating a long-term value, not only for shareholders but also for the other stakeholders, based on the ability to take opportunities and manage risks arising from the changes of the context.

In particular, sustainability was based on the pondering of three essential dimensions - the so-called Triple Bottom Line - the economic, social and environmental one, trying to pursue together a maximization (Elkington, 1997).

The third mainstream derived from further studies concerning the analysis of social performance and it flowed into the theme of social audit, defined as process of systematic and periodic study and evaluation of social performances of a company.

It was, therefore, necessary to monitor the company in order to control activities having a social impact, to check the adequacy of the designed resources and the procedures of social management, to evaluate the degree of coherence between achievements and planned targets.

The fourth line of thought, finally, included numerous contributions realised to deepen on the one hand, the determinants that encouraged companies to social communication and, on the other, the most successful techniques and methodologies for socio-environmental reporting, seen both as fundamental point of connection between action and results and as a means to exploit the synergies between the social strategies and the financial economic performance of the company.

It was in this context that the studies in the field of social reporting, environmental reporting, sustainability reporting and rating process and international standards for the certification and comparability of corporate 
social performance were introduced.

\section{Survey Objectives and Methodology}

The recruitment of socially responsible behaviours allows the corporate system to operate in full compliance with environment, a condition necessary to preserve, first of all, the economic achievements, and also to lay the foundations for the process of further development. Accepting this theory, it follows that company should integrate its system with those of other agents, while providing a circuit capable of communicating information appropriately such as integrations and subsequent choices.

This collaborative vision of formulation of strategies implies obvious consequences also in the distribution of the created value: it should be used for the long-term functioning and growth of the company. That means tangible and intangible capital investments to improve business competitiveness and its ability to respond appropriately to the expectations of social stakeholders. In this perspective, income is configured not only as aim, but as resource which, created by business coordination, becomes a driving force to supply the internal cohesive forces and the ability to interact with appropriate responses to the needs of the reference field.

The adoption of this perspective involves the interpretation of the strategy as a pro-active vision of business development, where economic needs are combined with the social and ethical ones, with a relation of mutual positive influence (Molteni, 2004). Nevertheless, it confirms that company constitute the privileged place to research and pursue the growth of productivity, where using resources to meet expectations and needs, generating thus new resources that can be invested in meeting the expectations of society, starting again a virtuous cycle, productivity.

The objective of this research is to determine whether and to what extent there has been an impact on business performance, following the implementation of a specific CSR project in a local public transport of a medium/large company (turnover $€ 56$ million, No. of employees 1341).

Starting with the assumption inherent to social responsibility, that companies and society are interdependent realities, according to a recent contribution by Porter and Kramer, the problem of the distribution of value can be observed according to a vision that do not consider the success of the companies and the social good as a zero sum game. The interaction with the territory involves the survey of a series of value flow from and to the company. The problem, therefore, is to identify, first of all, the direction of the value flow (Quagli, 1995, p. 52).

The interdependent relationship between company and environment becomes increasingly inflexible, and the boundary between company and environment tends to fade, bringing changes to the concept of social responsibility, uncovering the idea of corporate social integration, in a report that can be described as follows:

- Companies exploit resources (economic, social, and environmental) from the competitive system to conduct their own activity;

- The same companies, at the end of the production process return value (economic, social and environmental) to the competitive system;

- The process begins again with a new withdrawal: if the company has given to the competitive context an added value compared to that taken, the same company will enjoy it, by reintroducing these new resources in its own production process (Porter \& Kramer, 2006).

Subsequently, on the one hand it is necessary to wonder where and how much value is taken before the production process and returned and, on the other, how that value may be maximized in favour of stakeholders in the territory (or reduced in case of negative impact) in a logic in which a company shows its competitiveness in coherence with the dynamics of the territory and the area/field they belong to. In this case, however, the issue of upstream resources is a particularly sensitive because of a public company.

The analysis of this case will focus in particular on the second phase, that distribution / return of value, assuming that the true social integration is carried out not only by implementing strategies that simultaneously pursue the goal of making a service to civil society, achieving benefits for the company. Rather, the implementation of these specific strategic choices, which seem to have the nature of competitive strategies, could even live with absolutely irresponsible behaviour toward employees, minority shareholders, lenders, suppliers, customers, variously marginalized the organization's goals. The overcoming of social responsibility in favour of social integration would be achieved, however, in the process of value creation, whereas the organization establishes as objective the inclusion in its strategies of the expectations of all the agents partaking in the development of the productive function, widely understood. Thus, the objective of profit growth, while remaining firm in its intention, it would be oriented to a long-term perspective in which responsibility or, social 
integration, would attain to create value in a way compatible with the expectations of social partners to ensure, at the same time, the stability of the company (Gabrovic Mei, 2000, p. 566).

The methodology used is therefore empirical, based on a company case study presenting characteristics of great interest:

-For the special process carried out, starting from an analysis of the socio-cultural context, after which the company noted that, especially in some sections, a large proportion of the population and, consequently, its catchment area is represented by immigrant population;

-For those who have been involved in implementing the project, both internally and externally, with the cooperation developed between profit and non-profit entities;

-For the integration of social and business objectives, particularly acknowledged as qualifying feature of the project and for that reason it has received national and international awards.

\section{Case Description-Features of the Company}

CTP, acronym for "Compagnia Trasporti Pubblici di Napoli" (Public Transport Company of Naples) is a public limited company, established in its current legal form in 2001, running public transport between the city of Naples and its province. Its history, however, began in 1884 with the establishment of a private Belgian company, called Société Anonyme des Tramways Provinciaux de Naples (SATP).

CTP Plc, is currently operating the urban and suburban public transport service in the provinces of Naples and Caserta, and urban in the towns of Acerra and Pozzuoli, for a total of 72 municipalities served by a network of 140 bus lines running over $2300 \mathrm{~km}$, with a catchment area of 1,700,000 inhabitants. In 2008 it recorded a turnover of approximately EUR 56 million and employed 1,341 workers. That same year, carried approximately 33 million passengers on its buses.

Its administrative headquarter is located in Naples. It also owns two offices in the province of Naples and one in that of Caserta, used for the storage and maintenance of vehicles.

Since 2001, CTP has extended its sphere of interest in activities and services related to mobility, taking part in the establishment and management of the following companies:

- STI Plc (Integrated Transport Services), with shares owned by CTP Spa and STM Plc (Transport and Mobility Services), respectively $60 \%$ and $40 \%$ for the operating of urban public transport services, escalators and elevators in the city of Potenza. During 2005, however, the company was liquidated;

- CitySightseeing Napoli Ltd., established with the companies ANM and EAV for the management of tourist transport service in the city of Naples;

- NA-MET, with shares owned by CTP, ABC Italia and Thecla, born for the design of supply infrastructures and depots for CNG-powered fleet, management and maintenance of depots, vehicles and petrol stations. Na-Met also manages the distribution system to store methane in Arzano, at disposal of CTP fleet, also providing for the sale of methane to the public;

- SIS (Service company for business and development), in partnership with Formimpresa and EQC, which is active in consulting and organizational development and Human Resources management and has as its aim the promotion and implementation of initiatives on employment and cultural, socio-economic development policy, also through staff training activities in terms of protection and social commitment. It aims, also in cooperation with public and private Italian, European and international entities, at sustainable development of the company;

- Vesuviana Mobilità Ltd, established in 2003, of which CTP is shareholder for $40 \%$, manages urban public transport services and parking areas in the towns around Vesuvius;

- it also participates in Torquato Tasso Coop., to ATI for the provision of tourist transport services in the town of Sorrento.

The company also participates, even though not-significantly, in Unico Campania Consortium (Consortium of 13 public transport companies managing the tariff integration in Campania), in ANEA (Naples Agency for Energy and Environment, independent and non-profit entity that promotes the efficient use of energy, the use of renewable resources and the protection of environment) and ACF ASI Consortium (II level Consortium for the management of common services to all companies in the Development Area).

Corporate governance is characterized by the so-called "Italian system". The Board of Directors is currently composed of three members. It is elected by vote of the ordinary assembly and it is invested with the powers of ordinary and extraordinary administration; it can, therefore, perform all the acts necessary for the 
implementation and achievement of social purposes, except those reserved to the shareholders as provided by law.

Internally, the Board of Directors appoints the President who represents the company and provides the General Director, the Directors and employees with the directives for the implementation of the decisions of the Board of Directors.

Employees or directors of CTP, are not part of the Board of Directors to which is due the appointment of the General Director.

The remuneration for the President and the Board of Directors are determined by the Shareholders Assembly on the occasion of the appointment and, currently, there are not incentive schemes linked to the performances achieved.

\section{The Organization of CTP}

The company has been particularly careful in recent years in terms of investment in quality and social responsibility. In addition to the implementation of some social responsibility projects, it invested mainly in the achievement of the following certifications:

- Quality Certification, issued in 2001 according to ISO 9001 international standard, maintained up till now by the company as guarantee of implementing a management system underlying the various business processes and which aims at the customer satisfaction;

- Certification for Social Responsibility, issued in 2002 according to SA8000 standard; its implementation in the company confirms the conduct of business according to an ethically correct behaviour;

- Environmental Certification, issued in 2005 and adhering to ISO 14001 standard. This underlines the company's commitment to the numerous initiatives promoting a mobility compatible with respect for the environment as well as the attention to the control processes that impact on environment;

- CEEP-CSR Certificate, following the analysis of the results achieved in the activities of the project "I discern", co-financed by the European Commission to promote and study the implications of corporate social responsibility in public or mixed service companies.

The strategic choice is to direct management towards policies in condition to cope with market, increasing reliability, transparency and confidence of stakeholders and social partners in relation to their social performance.

\section{The Implemented Project}

CTP aims at promoting new parameters in the evaluation of business performance by integrating environmental and social components to the economic profile: encouraging the project Contact.

It is worthy to remind in which area the project fits in with, in fact CTP, thanks to the system of Social Responsibility and SA 8000 certification, acts as virtuous and driving force of the apparatus in which business operates, demonstrating the compatibility between ethical principles and more strictly economic activities of a company.

Business management, based on an integrated approach among Quality, Environment, Safety and Social Responsibility, thereby contributes to the development of a "sustainable system", ensuring and showing its social responsibility through its own corporate social system.

SA8000 certification, we remember, is a voluntary adhesion-standard born in 1997, with the aim to establish ethical standards based on the respect for human rights at work, pursuing through the certified companies and the chains of their suppliers, the creation of a system focused on continuous improvement and on prevention in the perspective of the sustainable development.

By a temporal point of view, it represents the first official international standard of a certification in matter of Social Responsibility which aims to allow the establishment of a proper Human Resources management system.

SA8000 certification also includes the choice of:

- Coping with market and new business challenges with regard to fundamental ethical values, increasing the strength, transparency and trust of the stakeholders and of social partners in relation to their social performance;

- Having a systematic approach to the issue of Human Resource Management;

- Defining a managerial system based on prevention rather than correction and focused on the continuous improvement of CSR. 
The project "Contact" presents absolutely innovative and experimental features: it is, indeed, the first project proposed in Italy by a Public Transport Company, to pursue socio - cultural integration of ethnic groups of the territory, focusing on the reconversion of human resources present in the company and on the introduction of a new figure, with specific skills: the cultural mediator on the means of transport. The action of "Contact" is an attempt to create a context where social relation is not reduced to a mere use of labor force, nor it is just conceived to form new buyers of transport service, but it has the aim to engage, on a social, cultural, political and economic level all the actors of the local community.

The project involved public, private and non-profit realities such as: the Province of Naples, CTP Public Transport Company, the Caritas of Naples, La Locomotiva Social non-profit organizational Co-operative.

CTP intended to enhance Human Resources management, both in the company and on the territory, through the implementation of this project, according to its mission that states: "respect for the individual - the immigrant as a citizen, bearer of rights and duties, the integrity of the person, equal opportunities, justice and the belief that soon these values will be contribute to create a positive relationship between the two communities.

The project stems from the analysis of two particular aspects, concerning the transport service and the local community where the service is performed:

- On some served routes, the percentage of clients belonging to the immigrant population from foreign countries exceeds $75 \%$;

- In particular on those routes, the sense of insecurity of customers and operators is very high.

\subsection{Migration}

The presence of foreigners staying in Campania, represents the $3.9 \%$ of the national total, however, the $70 \%$ of them located in the provinces of Naples and Caserta, where CTP operates.

The countries of Northern Africa exhibit $16.5 \%$ of presences to which is added a $6.9 \%$ coming from Western Africa with a strong incidence of Nigerian and Senegalese people.

Most of them work or live on the Domitian coast (coastline that stretches between Naples and Lazio). The increase of requests for residence permits for family reasons, also testifies a growing stabilization of the phenomenon of migration in Campania. Usually, in fact, there is family reunification when the migrant has achieved a certain degree of integration into the social and working context of the host country.

\subsection{The Sense of Insecurity}

The situations of degradation and marginalization in which they live, undergo immigrants to significant hardships, particularly for the lack of reception facilities. The lack of knowledge and information about their own rights, language difficulties and, in most cases, lack of job and the first support network established by the family, relegate, these people in absolute solitude.

Indeed, the main problem is often the feeling pervading the immigrant, of belonging no longer to the society of origin and, at the same time, not belonging yet to the host country.

Even the lack of language knowledge, then, besides not encouraging the integration, causes also a feeling of fear and mistrust in dealing with what is not understandable and therefore feared, anyway.

The mission of CTP, which includes the role of facilitator of cultural integration, development of public transport use and reduction of pollution, has strongly encouraged the company to face in all places the problem of insecurity. The first stage, essential to address any phenomenon, is that of the acknowledgement of it, and consequently, the first efforts are directed in the monitoring of criminal events, often linked to the presence of settlements of immigrants, sometimes clandestine.

The social system, thus impacting the workers and the company is exposed daily, perhaps more than any other local reality, to the security risk, and for this reason that it has been decided the necessity to shorten the distance between user and operator, or aim at a cultural and territorial integration of the company in that area.

CTP Directorate has agreed on the indispensability of staff training, sure that only by increasing cultural and technical capacities in relating to the problem and its specific events, each operator may see improved confidence and sense of security in the carrying out of its functions.

\subsection{Phases of the Project}

The project was implemented through a path consisting of two parts: a training and an operative part. The training part was split into two phases: one informative and the other one formative providing essential 
knowledge and new methodological tools, useful to intercultural communication and to collective self-organization of immigrants or mixed, the networking, a "research" on their cultural identity, migration processes and issues related to it.

The operational part included the use of knowledge-skills acquired thanks to the intervention of mediation on bus routes, previously identified by the transport company. Participants, trained in mixed groups - CTP Italian operators and immigrant mediators - besides acting as mediators, gave life to a sort of an itinerant touring information service, a sort of social workers on the road, in a perspective of e mutual exchange of values, rules , expectations, thought patterns among different cultural identities.

The project started in 2003 and lasted until the early months of 2009, affecting different geographical areas and lines. Should be noted that the project was initially funded by the company itself; in a second phase, the company's employees decided to cofinance the investment devolving the increase of the value of meal vouchers.

\subsection{Methodological Assumptions of the Data Analysis}

Over the years, there was a shift from a social context focusing on the needs and expectations of stakeholders to an approach based on stakeholder management with the aim to resolve any conflicts arisen among the different interest groups, becoming thus an issue of strategic importance (Clarkson, 1995; Golinelli, 1998). The increasing complexity of business has generated a change in corporate governance systems that have re-oriented corporate values, in particular bringing to life a new way of managing relationships with stakeholders. Indeed, stakeholders have assumed greater strategic importance for the company to achieve internal and external legitimacy. The internal legitimacy is acquired by the consent obtained from the human resources employed in the company, or improving the quality of management for better economic performances. The external legitimacy comes from the awareness of the company to act in accordance with community values and moral ethics.

The company should, therefore, achieve internal and external approval, taking care not only of its own economic performance but also of the social one, creating, in this way, a social strategy. There are different definitions of social strategy that followed, including those of Matacena (1993), Coda (1998), Chiesi, Pellegatta and Martinelli (2000), Allen and Husted (2000), which are well summarized by Chirieleison (2002): "The social strategy can be defined as the complex of decisions seeking to achieve social objectives, namely to provide added value to its own reference context and to maximize the coincidence between the values of the company and those concerning social interest groups, in order to gain a competitive advantage through consensus and legitimacy, maintaining the vital part of economic equilibrium, too."

The economic and social aspects should thus be in a working mutual relationship, or rather social policies should be able to strengthen the stability of a company (Coda, 1984). Making this type of evaluation is difficult, because the company is not always able to assess the economic benefits stemming from social policy choices. Indeed, the effects of social strategies, and, therefore, of the investments in actions of RSI can be assessed only over a long period (Coda, 1990). It gains value, therefore, not the series of responsible actions undertaken by the company but, rather, the fact of being included in a corporate strategic approach aimed at sociality. So, there is a shift from a social strategy to a strategy for sustainability (Knoepel, 2001), to create value for the company over the long -term for all the stakeholders seeking to combine the three basic dimensions of the triple bottom line (Elkington, 1997): the economic, social and environmental fields.

Neglecting the processes of social development strategies (Chirieleison, 2002, p. 105), to identify a possible way to analyze the relationship between social policies and socio-economic performance, we observe that, in literature, there are two different mainstreams.

In the first version, the CSR actions generate costs producing a disadvantage relative compared to the other companies which do not implement these actions (Aupperle, Carroll \& Hatfield, 1985). The latter may achieve a lower labour cost (using e.g. underpaid labour) or cost savings (for lack of laws to be respected), for lower incidence of taxation (based on the country where they implement production activities) and for the shortest incurring additional costs for investment in social responsibility projects.

Another mainstream, on the contrary, considers that there are synergies between investments in social policies and the socio-economic performances of a company, in particular through this kind of investments, social legitimacy (both internal and external) enhances generating positive effects also on the economic performance.

One possible analysis is proposed by Chirieleison (2002, p. 154) through the identification of the key areas which can show effects on socio-economic performance, including:

- Capital market; 
- Human resources;

- Customers-consumers.

In the first case, it is necessary to consider the extent to which the investor is influenced by economic returns and social performance in its investment decisions.

Human resources, according to the Resource Based Theory (Wernerfel, 1984), represent strategic assets because they are rare, not replaceable, difficult to imitate and they represent, therefore, a source of competitive advantage of the company (Barbey, 1991; Grant, 1995; Collis \& Montgomery, 1995).

Chilierson (2002) argues that in order to lever human resources, as strategic factor of success and social performances, it is necessary to operate on two aspects:

- Management and employee motivation;

- Attraction of professionalism for the company.

RSI actions, directed to employees, certainly generate positive effects on the internal legitimacy of the company and better working conditions, in terms of economic benefits for the company expressed, for instance, by: lower turnover, reduced absenteeism, a reduction of control costs for the trust developing in the company.

CSR actions directed at employee motivation may include:

- Direct actions addressed to employees on their request to improve workplace safety, working environment, participation in internal decision processes, etc.;

- Social actions addressed to the community or natural environment, so that employees will be more motivated in doing their job, being aware that they are contributing to social projects.

The attraction of professionalism in the labour market can occur with:

- Activities in favour of employees through the dissemination of positive information about the quality of relations with the unions, the promotion of stock option plans (ie. participation of workers in business results through shares), employee participation in decision-making, benefits offered, supplementary social security contributions, etc.;

- Social activities carried out in favour of the local or international community, for the respect of natural environment, the improvement of the working environment or the quality of services/products offered on the market, so that the employee acquires an increasing self-esteem thanks to the social actions of the company to which he belongs to.

It is possible to analyze the effects of social strategies on consumers only if the latter consider RSI an element of appreciation in making their own purchase decisions. In particular, social policies can generate positive effects on customers-consumers through:

- Social actions creating added value to the product/service or to the production process of the latter, and if that value is perceived by the customers-consumers;

- Social actions affecting the system of social and ethical values of clients-consumers; in fact, the social actions promoted by the company include: the financing of cultural, sporting initiatives, donations to NGOs, PNA, etc.. , commitment to the respect of human rights, and so on.

\subsection{The Results of Empirical Studies}

Over the last thirty years a lot of enquiries on the relationship between corporate social performance (CSP) and corporate financial performance (CFP) have been carried out. The results of these studies were contrasting, for some the relationship between CSP and CFP showed a positive relationship, for others a negative one and for some others there is any relationship yet. According to Ullman (1985) the reasons for such different results was due to the methodological limits of the researches concerning both the inadequacy of the theory and the inadequacy of the databases used.

According to Ullman it was necessary to consider not only the relationship between CSP and CFP, but also social communication. Indeed, the enquiries that have been carried out were about:

- the correlation between social communication and social performance;

- the relationship between social and economic performance;

- the link between social communication and economic performance. 


\section{The Process of Social Performance Analysis}

Social performance analysis may have internal or external purposes in a company. However, here are some steps identified by Chierleison (2000) to which it is necessary to refer to throughout this survey, in order to describe the approach to be used:

- Definition of social performance and selection of the dimensions to be analyzed;

- Choice of analysis parameters concerning CSP;

- Definition of quali-quantitative variables and indicators analysis parameters;

- Analysis of a possible synthesis of performance.

There are several definitions of CSP, that creates many problems for surveys. "Carroll made the first observations about the concept of CSP, it was composed by three elements: RSI level of the company; commitment in social issues; corporate social responsiveness.

For the purpose of the present study it has been chosen the description of Wood (1991) who identified three main features:

- Corporate social responsibility (or social obligations arising from the will to promote a company's internal legitimacy);

- Corporate social responsiveness (social strategies concerning the assessment of environment, stakeholder management and management of social problems);

- The results of the company arising from actions undertaken by RSI.

The choice of parameters to be analyzed depends on stakeholder mapping, on corporate dimensions that must be analyzed or it is to be referred to a specific action of RSI.

The analysis of parameters to be analyzed can be done through two models, an analytical direct model and an indirect synthetic model. The analytical direct model is based on the identification of indicators expressed both in monetary terms and through a direct and objective evaluation of the parameters of social responsibility. These indicators should be easy to be measured, the cost of measurement should not be too high and it is also necessary their availability for the measurement data. The synthetic indirect model evaluates the social performance through other methods such as: the content analysis, the distribution of added value and the surveys on corporate reputation.

The content analysis (Hackston \& Milne, 1996) of annual reports or other documents produced by the company, consists of the analysis of the space dedicated (in quantitative and qualitative terms, too) to social issues. This analysis can be performed to assess the social strategy of all the company or as regards RSI specific plans or specific stakeholders.

The analysis of the creation and distribution of added value (Gabrovic Mei, 1984) shows the redistribution of added value to the various stakeholders. Such an analysis presents some advantages regarding the objectivity of the data considered (indeed, they stem from the accounting system), but the limit is that of not considering all the corporate stakeholders. Moreover, it do not allow to assess the economic and financial value distributed to business partners, neither in terms of adequacy nor of satisfaction with regard to their expectations.

The enquiries on corporate reputation consist of the evaluation, through questionnaires, of the satisfaction on behalf of representative parties of stakeholders. One limit of such a study is just the assessment made by these parties and this creates problems of response comparability. In addition, there is also the limit of a survey carried out through an interviewer, however, that may be overcome by using standardized interviews.

As a rule, both measurement models are used and this often generates a reduced objectivity, though it sometimes allows to retrieve information and assessments that otherwise would be lost.

Not only in the academic area, it is hoped to determine a possible synthetic index of the PS, a first problem would be that concerning the weight to attribute to the different dimensions of social performance and the aggregation of results. Several attempts have been developed in this direction, since the Seventies with Moskowitz. To deepen this aspect it is necessary to focus on further studies.

\subsection{Measurement of the CSP}

The aim is to make an assessment of CSP with regard to the social strategy promoted by a specific RSI project, the project "Contact".

Recalling the methodological approaches described above, it is necessary to consider the definition of Wood for 
the determination of CSP concerning the project Contact:

- The project aims to promote socio-cultural integration of ethnic groups in the territories where the company operates;

- The strategy employed by the company is oriented to: the background within the company (or rather to face the issue of security with regard to the difficulties among the operators of CTP and the integration of the users of transport service represented by a high proportion of immigrants with problems of insertion into the social fabric); to promote the integration of immigrants by providing an additional service on buses;

- To assess the impact inside and outside the company about: - human resources management - local community -immigrants both in qualitative and in quantitative terms.

The parameters for the analysis of the results expected from the project, both qualitative and quantitative, are showed on the basis of customer-user category and on staff category.

In particular, the approach developed concerns both an analytical direct method (through the analysis of financial statements, other accounting records, sustainability report, etc.) and the indirect method of analysis (particularly using qualitative surveys conducted through interviews).

On the basis of the description above, the effects deriving from RSI actions can influence investment decisions in the capital market, the motivations of employees and consumer choices.

In the present survey it is assumed that the project Contact could produce effects on:

- Human resources;

- Customers;

- Involvement of local and institutional stakeholders.

With regard to human resources, it is possible to classify the project Contact as a social intervention of "other type", namely implemented in favour of the local community and, particularly, for the foreign community; however, it also produces effects on the internal legitimacy of the company. In fact, the staff is involved in the project both in the professional training and in the improvement of workplace security. In fact, promoting a climate of trust on behalf of users towards operators of transport services, fosters communication and the improvement of business climate.

The items to be considered for the project's effects on human resources are:

- Reduction in turnover;

- Reduction of absenteeism;

- Reduction of control costs to achieve the best business climate;

- Participation of the number of employees in the project;

- Participation, also in economic terms, on behalf of employees, in the project (meal tickets);

- Improving relations with the unions.

In terms of investment on human resources, it is essential to consider:

- The hours of training to which employees participated in;

- The economic resources invested in education;

From the perspective of clients, in order to evaluate CSP with regard to the project Contact, it is important to assess:

- Customer satisfaction according to:

- Safety on board;

- Behavior and look of the staff;

- Service information;

- Complaints;

- Punctuality, regularity, frequency;

- Increase in the sales of tickets;

- Types of complaints (crowded buses, quarrels with the staff, failure to purchase tickets, noise on board, 
aggressions and vandalism, fouling buses, irregular occupancy of seats, disputes among customers, lack of information on the bus lines).

For what concerns, the evaluation of the project contact, it is essential to assess the ability to build networks with other regional or local entities or other parties belonging to the no-profit field and not only:

- Number of the parties involved;

- Typology of the parties involved;

- Replicability of the project in other regions;

- Awards for the project.

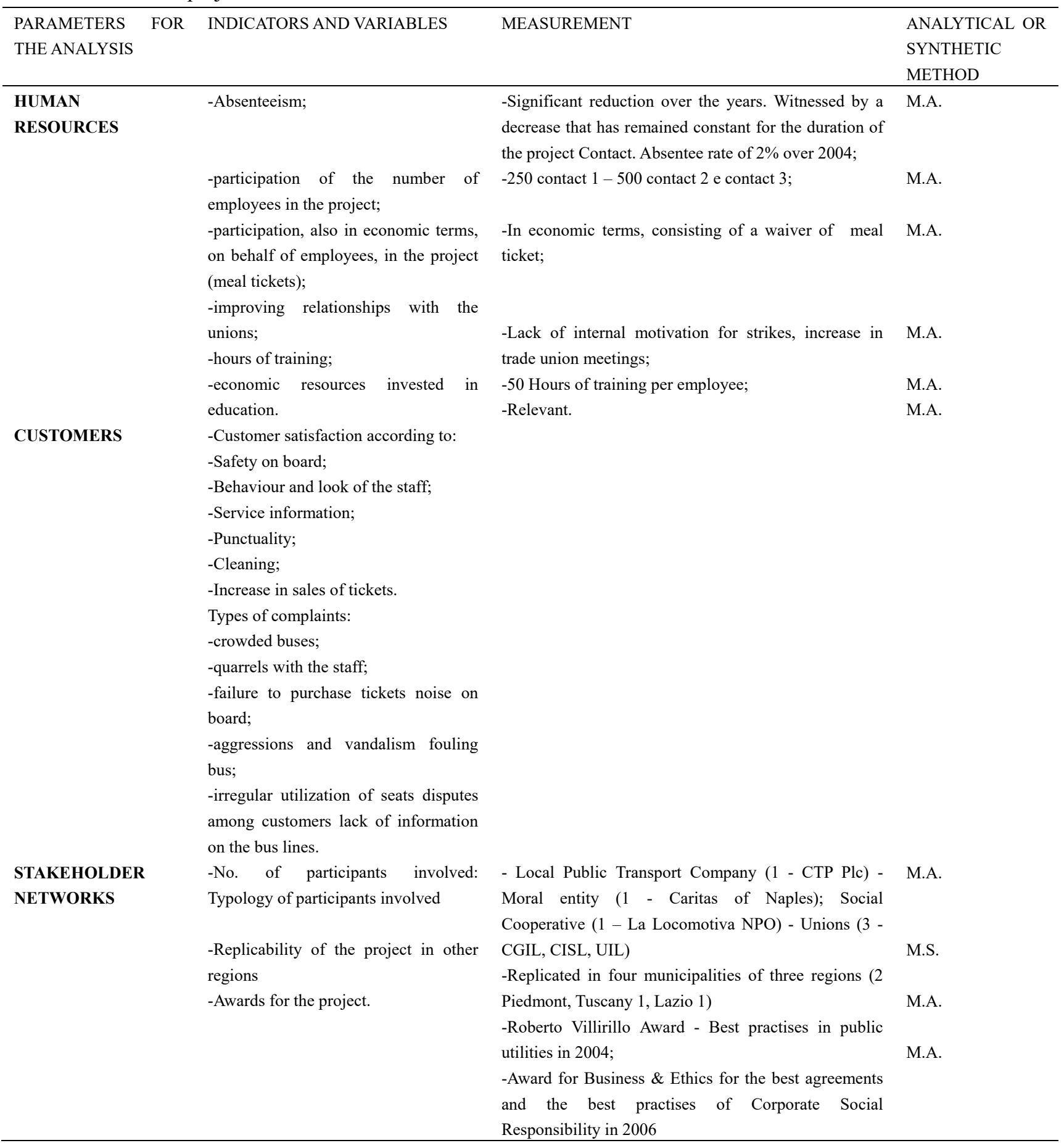




\subsubsection{Measurement of the Indicators}

\section{Customers Area}

A very important issue arises in relation to the assessment of increased sales of the number of tickets. This is a very significant aspect for the evaluation of the impact of the project on economic performance.

In fact, since 2003 it has been created one ticket (Unico Campania), valid for the entire region, that allows the employment of all the available means (for example, Trenitalia, Circumvesuviana Alifana, SEPSA, ANM, ACMS. AIR, SITA Metro del Mare, etc..) with variable fares depending on the destination area.

The effect of this system has increased the number of passengers, but it has reduced the number of tickets sold directly by CTP, and, consequently, their revenue.

With one ticket it is possible to make use of more trips within the same tariff zone and it is valid for 90 minutes for urban areas and 120 for non-urban areas.

The revenue deriving from the sale of tickets is received by Consorzio Unico Campania, then, on the basis of a sample survey conducted annually by the Consortium on users, determines the shares of revenues attributable to each carrier depending on the usage of its means of transport. This share of revenues is determined on the basis of the evaluation of the average number of passengers, except the rate of evasion detected by sampling method on board means of transport for each company.

This evaluation system, over the years, has affected the allocation of revenues in favour of CTP, which is one of the company with the highest level of evasion.

For this reason, it is difficult to highlight the impact of the project Contact, over the years, on a possible increase in revenues.

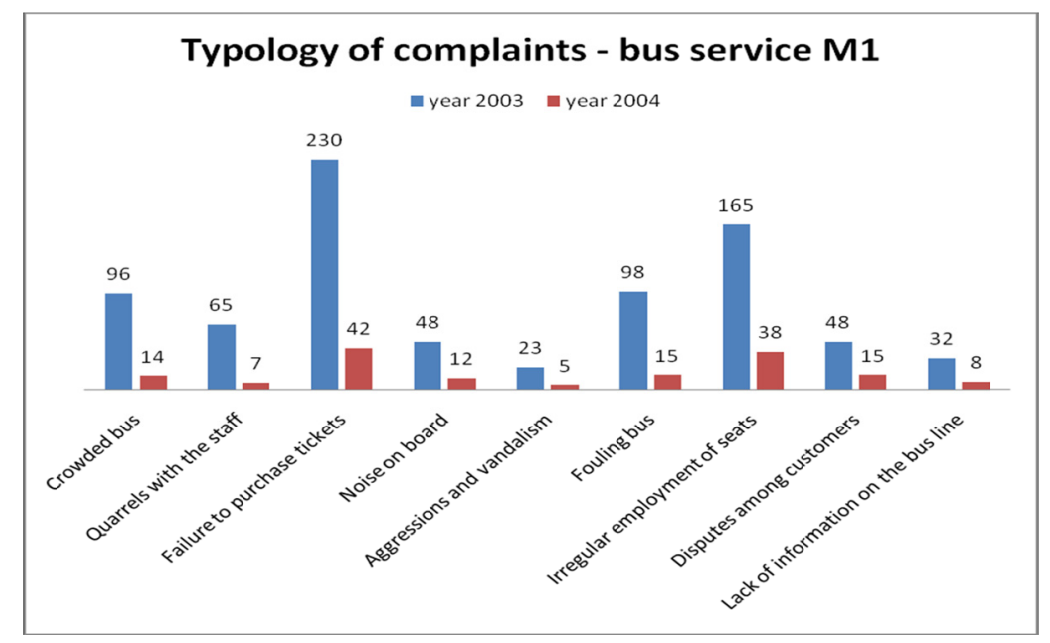

Through the indicator concerning the typologies of complaints received in 2003 and the comparison of the results obtained by the interviews in 2004, an evident improvement comes out, including a noticeable decrease of the failure to purchase tickets.

It is also important to have an overview of all the complaints about bus service offered by CTP, the following table shows a significant decrease of complaints. 


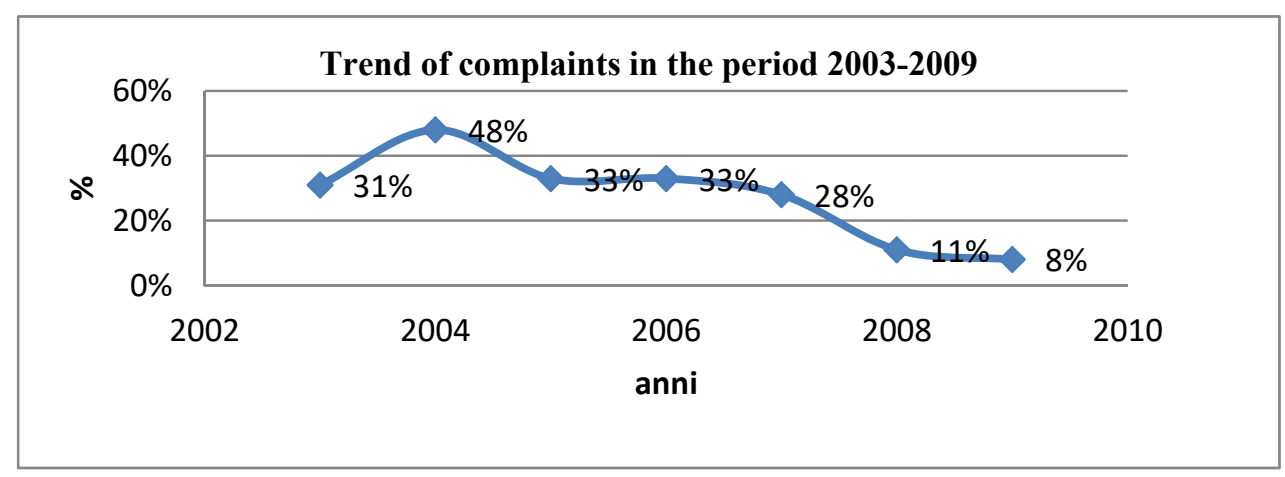

Since 1999, CTP performs customer satisfaction surveys with the aim to monitor and improve the quality of the service as well as the relationships with users. During 2009 a study it has been conducted a survey on costumer satisfaction which included the programming of the following number of interviews:

\begin{tabular}{lll}
\hline Day & No. Interviews & Distibution \\
\hline Weekday & 1600 & $80 \%$ \\
Pre-holiday & 260 & $13 \%$ \\
Holiday & 140 & $7 \%$ \\
Total & 2000 & $100 \%$ \\
\hline
\end{tabular}

With regard to the total of bus lines involved in the interviews, amounting to twenty-nine, all the lines involved in the project Contact have been taken into consideration as shown in the table:

\begin{tabular}{lllll}
\hline LINE & ITINERARY & Weekday & PRE-HOL. & HOL. \\
\hline M1NB & CONTACT & 130 & 30 & 18 \\
M1R & CONTACT & 51 & 12 & 6 \\
M21 & CONTACT & 49 & 11 & 0 \\
M45N & CONTACT & 60 & 14 & 8 \\
M45R & CONTACT & 55 & 12 & 9 \\
\hline
\end{tabular}

This table shows a differentiation of the interviews according to the day when they were made: during weekdays, holidays or pre-holiday.

This survey allows a comparison, during the years 2003-2009, of the evaluation of items characterizing the quality of transport services. Such a fact is related to all the lines of transport: from 2003 to 2006 it has occurred an improvement for almost all the qualitative factors and a collapse related to security factor on-board and cleanliness of transport service.

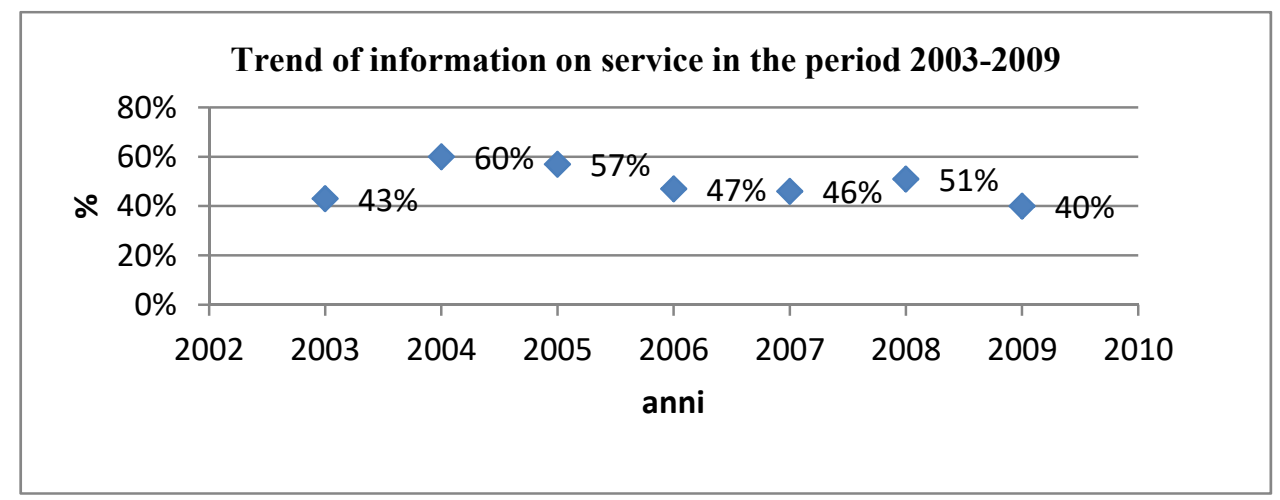


The aim of the present study is to succeed in identifying the possible effects of the project Contact as regards customer satisfaction for the bus service concerned. This information are valid only for the year 2009 and they show the assessments on personal safety, punctuality and cleanliness of vehicles.
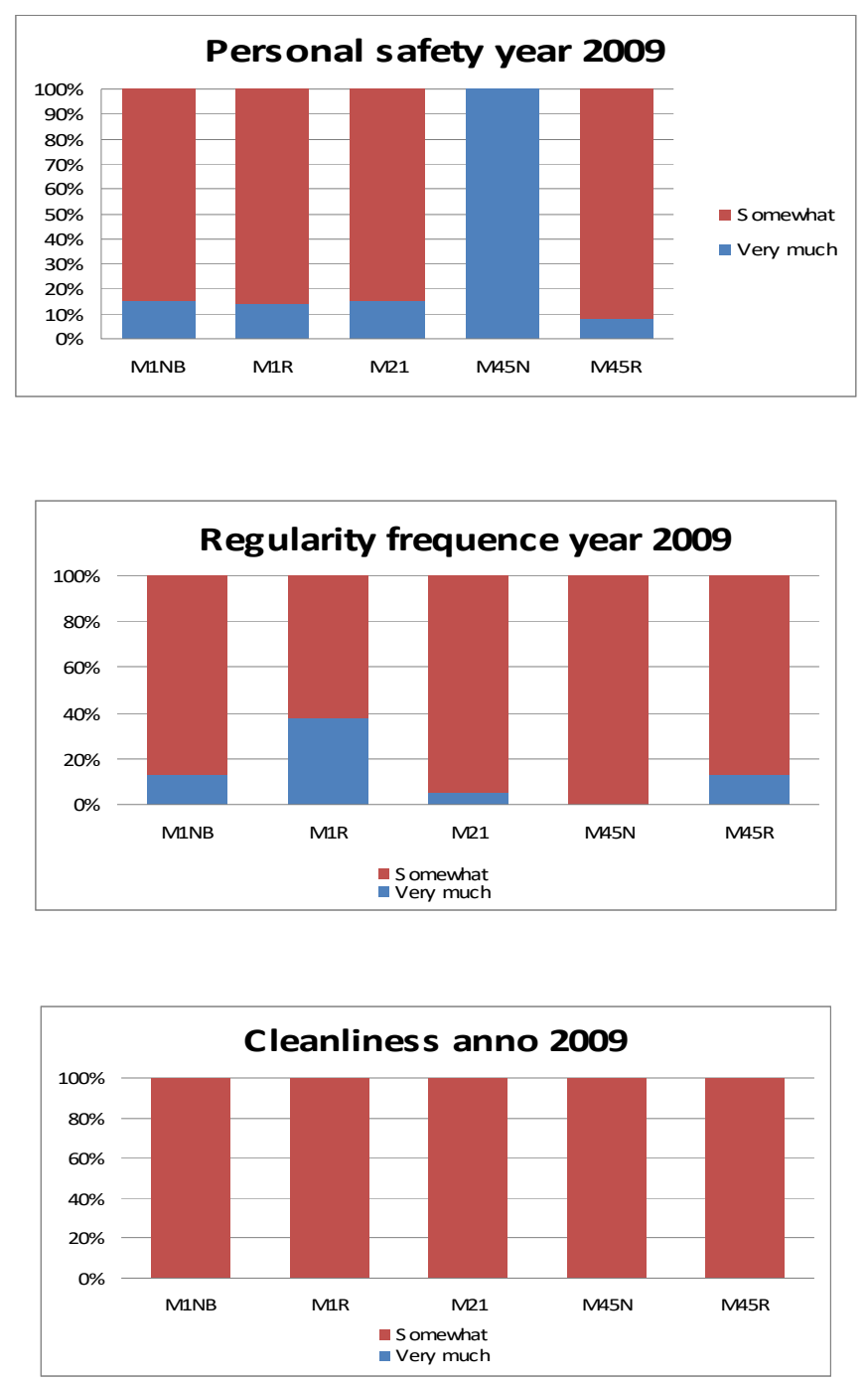

\section{Human Resources Area}

The indicators chosen to highlight the effects of the project Contact on human resources are of several kinds. It is essential to consider the number of employees in the company, which is composed approximately by 1,300 units . The number of participants in the project Contact has grown from 250 units, for the first year, to about 500 units for the following years. The project Contact, in its implementation phases, provided about 50 hours of training for the preparation of the intercultural project. The project Contact saw the participation of its employees not only through the use of educational training activity, but also through the economic involvement on behalf of the same employees for the financial support of the project. In fact, all the employees of CTP wanted to donate the increased value of their meal ticket for the project Contact.

The employees of CTP have been the first to benefit, along with users, the presence of cultural mediators on buses, that have allowed the facilitation of dialogue, knowledge and information among immigrants and drivers carrying out their work along the itineraries involved in the project. The improvement of business climate can be assessed both by employee participation in the project in economic terms, and in the decreased absenteeism, as well as in the evaluation, on behalf of employees, of a greater safety at work.

Another important item is the striking improvement in the relations with unions, in fact there has been an 
increase in union meetings and the lack of internal motivation for strikes.

\section{Stakeholders area}

A peculiar element of the project Contact to highlight through this category of people is that of capacity, on behalf of the company, to promote an investment capable of promoting the construction of a network among different parties to achieve a common goal.

The indicators used concern the number of parties involved (they are, currently, only six), but, above all, it is necessary to also highlight the different types of entities involved such as:

- A local public company (CTP);

- A non-profit organization (Caritas of Naples);

- A cooperative social (La Locomotiva);

- Trade unions (CGIL, CISL, UIL).

Another peculiarity, in assessing the social performance of the Project Contact, is its replicability. In fact, the project has been proposed in four other Italian towns of three different regions (two municipalities of Piedmont, a town in Tuscany and another one in Lazio).

\section{Final Considerations}

The survey conducted shows that the effects deriving from of RSI project implementation has surely positive effects on social performance. The aim is that to succeed in analyzing these effects by identifying the specific areas of the parties involved, and, consequently, to identify possible qualitative and quantitative indicators and measurement using both direct and indirect methods.

The data were collected are not sufficient to define with great detail the impact on social performance, but surely it is possible to see that most of the indicators observed have a positive impact on business management and not only. Indeed, the company, thanks to the project has increased both its internal legitimacy (through human resource management, decrease of absenteeism, participation and improving of business climate, training, higher workplace safety, etc..) and its external legitimacy through the perception of improved transport services offered on the bus services involved in the project and through the involvement and participation of other parties to it, as well as the recognition of the community through the national awards. A further positive effect has been the replicability of the project in two municipalities of northern Italy and two in central Italy. It is evident that the project Contact was definitely an investment, rather than a cost incurred by the company. It would be desirable to be able to define a synthetic indicator for the measurement of social performance, but for doing so it would be essential to consider not only one project, but the whole strategic social policy promoted by the company.

Another important aspect to investigate is the relationship between performance indicators and project implementation. If, in fact, the indicators were measured during the project implementation, the correlation between the trend of themselves and RSI has been established only in qualitative way.

\section{References}

Ackerman, R. W., \& Bauer, R. A. (1976). Corporate social responsiveness. Reston: Reston Publishing.

Alexander, G., \& Bucholtz, R. (1978). Corporate social responsibility and stock market performance. Academy of Management Journal, 21(3), 479-486. https://doi.org/10.2307/255728

Allen, D. B., \& Husted B. W. (2000). Is it ethical use ethics as strategy? Journal of Business Ethics, 27(1-2), 21-31. https://doi.org/10.1023/A:1006422704548

Aupperle, K. E., Carroll, A. B., \& Hatfield, J. D. (1985). An empirical examination of the relationship between corporate social responsibility and profitability. Academy of Management Journal, 28(2), 446-463. https://doi.org/10.2307/256210

Barbey, J. B. (1991). Firm resources and sustained competitive advantage. Journal of Management, 17(1), 99-120. https://doi.org/10.1177/014920639101700108.

Bowen, H. R. (1953). Social responsibilities of the businessman. New York: Harper \& Row.

Bowman, E. H., \& Haire, M. (1975). A strategic posture towards CSR. California Management Review, 18(2), 49-58. https://doi.org/10.2307/41164638

Carrol, A. B. (1979). A three-dimensional model of corporate social performance. Academy of Management Review, 4(4), 497-505. https://doi.org/10.2307/257850 
Carrol, A. B. (1991). The pyramid of corporate social responsibility: toward the moral management of $\begin{array}{lllll}\text { organizational } & \text { stakeholders. } & \text { Business } & \text { Horizons, } & 34(4),\end{array}$ http://dx.doi.org/10.1016/0007-6813(91)90005-G

Chiesi, A. M., Martinelli, A., \& Pellegatta, M. (2000). Il bilancio sociale. Stakeholder e responsabilità sociale d'impresa. Milano: Edizioni Il Sole 24 Ore.

Chirieleison, C. (2002). Le strategie sociali nel governo dell'azienda. Milano: Giuffrè.

Clarkson, M. B. (1995). A stakeholder framework for analyzing and evaluating corporate social performance. Academy of Management Review, 20(1), 112-113. https://doi.org/10.2307/258888

Coda, V. (1984). La valutazione della formula imprenditoriale. Sviluppo e Organizzazione, 82(2).

Coda, V. (1988). L'orientamento strategico dell'impresa. Torino: Utet.

Coda, V. (1989). Etica e impresa: il valore dello sviluppo. In Corno, F. (Eds), Etica e impresa: scelte economiche e crescita dell'uomo. Padova: Cedam.

Collis, D., \& Montgomery, C. (1995). Competing on resources: strategies in the 1990s. Harvard Business Review, 73(4), 118-128.

Committee For Economic Development. (1971). Social responsibilities of business corporations. New York: Committee for Economic.

Davis, K. (1960). Can business afford to ignore social responsibilities?. California Management Review, 2(3), 70-76. https://doi.org/10.2307/41166246

Davis, K. (1973). The case for and against business assumption of social responsibilities. Academy of Management Journal, 16, 312-322. http://dx.doi.org/10.2307/255331

Di Toro, P. (1993). L'etica nella gestione d'impresa. Padova: Cedam.

Elkington, J. (1997). Cannibals with forks. The Triple Bottom Line of 21 Century Business. London: Capstone.

Epstein, E. M. (1987). The corporate social policy process: beyond business ethics, corporate social responsibility, and corporate social responsiveness. California Management Review, 29(3), 99-114. https://doi.org/10.2307/41165254

Fombrun, C., \& Shanley, M. (1990). What's in a name? Reputation building and corporate strategy. Academy of Management Journal, 33(2), 233-258. https://doi.org/10.2307/256324

Frederick, W. C. (1960). The growing concern over business responsibility. California Management Review, 2(4), 54-61. https://doi.org/10.2307/41165405

Frederick, W. C. (1986). Toward CSR3: why ethical analysis is indispensable and unavoidable in corporate affairs. California Management Review, 28(2), 126-141. https://doi.org/10.2307/41165190

Frederick, W. C. (1994). From CSR1 to CSR2. Business \& Society, 33(2), 150-164. https://doi.org/10.1177/000765039403300202

Freeman, R. E. (1984). Strategic Management: A stakeholder approach. Pitman: Boston.

Gabrovic Mei, O. (1984). Il valore aggiunto dell'impresa. Trieste: Libreria Goliardica.

Gabrovic Mei, O. (2000). Misurazione delle performance e modelli solidali d'impresa. In Vermiglio, F. (Eds), Nuovi strumenti di comunicazione aziendale. Confronto di esperienze in tema di bilancio sociale. Torino: Giappichelli.

Giannessi, E. (1960). Le aziende di produzione originaria. Pisa: Colombo Cursi.

Golinelli, G. (1998). Impatto ambientale, responsabilità sociale, strategia d'impresa, implicazioni di carattere finanziario. In AA.VV. (Eds), Scritti in Onore di Luigi Guatri, Vol. I, Milano: Edizioni Bocconi Comunicazione.

Grant, R. M. (1995). Contemporary strategy analysis: Concepts, techniques, applications. Oxford: Blackwell Publishers.

Griffin, J. J., \& Mahon, J.F. (1997). The corporate social performance: Research direction for the 21 st Century. Business and Society, 36(1), 5-31. https://doi.org/10.1177/000765039703600102

Hackston, D., \& Milne, M. J. (1996). Some determinant of social and environmental disclosure in New Zeland companies. Accounting, Auditing \& Accountability Journal, 9(1), 77-108. 
https://doi.org/10.1108/09513579610109987

Ilinitch, A. Y., Soderstrom, N. S., \& Thomas, T. E. (1998). Measuring corporate environmental performance. Journal of Accounting and Public Policy, 17(4-5), 383-408. https://doi.org/10.1016/S0278-4254(98)10012-1

Johnson, H. (1971). Business in contemporary society: framework and issues. Belmont: Calif Wadsworth Pub.

Jones, T. M. (1980). Corporate social responsibility revisited redefined. California Management Review, 22(3), 59-67. https://doi.org/10.2307/41164877

Knoepfel, I. (2001). Dow Jones Sustainability Group Index: a global benchmark for corporate sustainability. Corporate Environmental Strategy, 8(1), 6-15. https://doi.org/10.1016/S1066-7938(00)00089-0

Matacena, A. (1993). La responsabilità sociale da vincolo ad obiettivo: verso una ridefinizione del finalismo d'impresa. In AA.VV. (Eds), Scritti in onore di Carlo Masini. Milano: Egea.

McGuire, J. B., Schneeweis, T., \& Sudgreen A. (1988). Corporate social responsibility and firm financial performance. Academy of Management Journal, 31(4), 854-872. https://doi.org/10.2307/256342

McGuire, J. W. (1963). Business and society. New York: McGraw-Hill.

Molteni, M. (2004). Responsabilità sociale e performance d'impresa. Milano: Vita e Pensiero.

Moskowitz, M. (1972). Choosing socially responsible stocks. Business and Society, 1(1), 71-75.

Onida, P. (1954). Azienda: primi principi di gestione e organizzazione. Milano: Giuffrè.

Porter, M. E., \& Kramer, M. R. (2006). The link between competitive advantage and Corporate Social Responsibility. Harvard Business Review, 12, 78-92.

Preston, L. E., \& Post, J. E. (1975). Private management and public policy: the principle of public responsibility. New York: Prentice Hall Englewood Cliffs.

Quagli, A.(1995). Introduzione allo studio della conoscenza in economia aziendale. Milano: Giuffrè.

Roman, R. M., Hayibor, S., \& Agle, B. R. (1999). The relationship between social and financial performance. Repainting a portrait. Business \& Society, 38(1), 109-125. https://doi.org/10.1177/000765039903800105

Sturdivant, F. D., \& Ginter, J. L. (1977). Corporate social responsiveness: management attitudes and economic performance. California Management Review, 19(3), https://doi.org/10.2307/41164709

Ullmann, A. (1985). Data in search of a theory: a critical examination of the relationship among social performance, social disclosure and economic performance. Academy of Management Review, 10(3), 540-557. https://doi.org/10.5465/AMR.1985.4278989

Vance, S. (1975). Are socially responsible firms good investment risks?. Management Review, 64(8), 19-24.

Waddock, S. A., \& Graves S.B. (1997). The corporate social performance-financial performance link. Strategic $\begin{array}{llll}\text { Management } & \text { Journal, } & 18(4), & 33-319 .\end{array}$ https://doi.org/10.1002/(SICI)1097-0266(199704)18:4<303::AID-SMJ869>3.0.CO;2-G

Walton, C. C. (1967). Corporate social responsibilities, Belmont: Wadsworth.

Wernerfelt, B. (1984). A resouced-based view of the firm. Strategic Management Journal, 5(2), 171-180. https://doi.org/10.1002/smj.4250050207

Willard, B. (2002). The Sustainability Advantage: seven business case benefits of a triple bottom line. Gabriola Iland: New Society Publishers.

Wood, D. J. (1991). Corporate social performance revisited. Academy of Management Review, 16(4), 691-718. http://www.jstor.org/stable/258977

Wood, D. J. (1993). Auditing the market: a practical approach to social auditing. London: New Economics Foundation.

Zadek, S. (1998). Balancing performance, ethics and accountability. Journal of Business Ethics, 17(13), 1421-1442. https://doi.org/10.1023/A:1006095614267 


\section{Copyrights}

Copyright for this article is retained by the author(s), with first publication rights granted to the journal.

This is an open-access article distributed under the terms and conditions of the Creative Commons Attribution license (http://creativecommons.org/licenses/by/4.0/). 